UDC 613.6.027

DOI: $10.21668 /$ health.risk/2021.1.19.eng

Review

\title{
ON CERTAIN ISSUES RELATED TO CHRONIC EXPOSURE TO OCCUPATIONAL NOISE AND IMPACTS EXERTED BY IT ON WORKERS' BODIES (LITERATURE REVIEW)
}

\section{V.F. Spirin, A.M. Starshov}

Saratov Hygiene Medical Research Center of the Federal Scientific Center for Medical and Preventive Health Risk Management Technologies, 1a Zarechnaya Str., Saratov, 410022, Russian Federation

Chronic exposure to noise becomes especially significant when it occurs at workplaces since it results not only in deteriorated life quality of workers but also in disorders in their occupational activities. Occupational sensorineural hearing loss (SHL) holds the $1^{\text {st }}$ rank place among occupational diseases caused by exposure to industrial physical factors. As any other work-related disease, sensorineural hearing loss makes it more difficult to preserve labor resources in the country and leads to significant economic losses. Given that, it is extremely vital to develop procedures for early diagnostics, to determine all possible risks that cause hearing loss directly or indirectly, and to create efficient prevention activities aimed at preserving health of workers exposed to noise at their workplaces.

We reviewed literature data published over the last 5-7 years and analyzed more than 100 scientific works on the matter. Our review covers data from 61 sources that are the most relevant regarding tasks we aimed to solve in this research.

Literature analysis allowed us to conclude that hearing loss caused by chronic exposure to noise at a workplace was a rather significant problem outlined by occupational medicine experts all over the world. It was shown that noise factor, apart from its direct impacts on the acoustic apparatus, produced apparent negative effects on many organs and systems causing various functional disorders in them which could directly or indirectly exacerbate hearing loss in workers.

Key words: in-plant noise, vibration, sensorineural hearing loss, prevalence, occupational hygiene, risk factors, primary hypertension, life quality, smoking, alimentary factor.

At present there are certain top priority activities that are to be accomplished by the state; when it comes down to labor relations and labor protection, a key issue here is to provide working conditions that allow minimizing risks related to a decrease in population in Russia and providing optimal age structure of the population. Given that, an urgent task that occupational medicine has to solve is accomplishing research works within state programs that are aimed at substantiating hygienic regulations. These regulations should provide safe and comfortable working conditions and reduce risks of occupational and work-related diseases for workers who have to contact adverse occupational factors at their workplaces.
Contemporary challenges make experts in occupational medicine develop new approaches to substantiating regulations that are aimed at reducing or eliminating adverse impacts exerted by occupational environment on workers. It necessarily requires developing a prevention system that secures long-term employable period, better life quality for workers, and greater prestige of occupations that involve exposure to adverse and/or hazardous hygienic factors.

Despite considerable success in the sphere, workers employed in many industrial branches still have to face exposure to hygienic factors at their workplaces; the situation occurs all over the world and such factors often exceed permissible levels greatly ${ }^{1}$. The

(C) Spirin V.F., Starshov A.M., 2021

Vladimir F. Spirin - Doctor of Medical Sciences, Professor, Leading researcher, Head of the Occupational Hygiene Department (e-mail: vlad.spirin2011@yandex.ru; tel.: +7 (8452) 92-30-48; ORCID: https://orcid.org/0000-0002-2987-0099).

Andrey M. Starshov - Researcher (e-mail: labergphys@gmail.com; tel.: +7 (8452) 92-30-48; ORCID: https://orcid.org/ 0000-0002-6499-0459).

${ }^{1}$ The Russian statistical annual data collection. 2017. Rosstat. Moscow, 2017, 686 p. (in Russian). 
problem is still persistent in many industrial brunches in the Russian Federation and it produces a negative effect on workers' employable period [1].

Coal mining, oil processing, metallurgy, agriculture, and aircraft building are among basic industries where workers are exposed to adverse hygienic physical factors. Naturally, occupational and work-related morbidity tends to be high in these branches and it exerts substantial influence on a demographic situation in the country and creates certain economic and social «tensions». X. Li et al. [2] point out there is a great contribution made by noise into SHL development among workers and provide data collected by the WHO proving that almost half a billion people all over the world have various problems with hearing. These hearing disorders cannot be cured and cause economic losses that are equal to approximately 750 billion USD.

World economy at the current stage in its development is aimed at satisfying growing social and communal demands of population; it unavoidably involves developing and applying more and more advanced production technologies and many of them still generate a lot of noise including noise being louder than permissible levels. Thus, even in industrially developed South Korea noise was detected to be louder than $80-90 \mathrm{dBA}$ in $64.6 \%$ cases examined at more than 52 thousand industrial enterprises where production involved noise generation.

Nowadays people have to face rather «noisy» domestic ecosystem. There are data on hearing disorders prevalence in $10.7 \%$ out of 164,770 examined people who were randomly selected for that study; these hearing disorders were not work-related or occupational ones [3].

Population studies taken in dynamics over 25 years indicated that workers suffering from occupational diseases had shorter life expectancy than healthy ones [4]. The authors showed that miners with occupational pathologies died from diseases that had etiological relation with their working conditions in $92.6 \%$ cases. And we should stress that only people with the best functional parameters were employed at that production since it involved exposure to a lot of adverse occupational factors; all workers had profound medical examinations prior to being employed. Obviously, should there be improvements in all the set of social-and hygienic factors including occupational ones, it will have a positive effect on overall workers' life expectancy [5].

But at the same time, there are certain issues at present that do not allow achieving proper quality of medical examinations for workers. When examining working conditions and medical aid provided for workers employed at industrial enterprises and in agriculture many authors mention serious drawbacks in periodical medical examinations (PME) and failure to detect and diagnose occupational diseases (OD) in workers [6-10]. It is often the case that two or three occupational diseases are first diagnosed in a worker during a PME accomplished in an occupational medical center; unfortunately, it usually results in growing disability among such workers $[11,12]$. I.V. Tikhonova also mentions poor quality of medical examinations provided for workers employed at production with loud noise at workplaces [13, 14]. We should also point out that in the RF clinical experts do not always pursue the unified approach to formulating a clinical diagnosis when there is hearing loss caused by exposure to noise. Unfortunately, it can have negative influence on overall assessment of the occupational pathology service in the country as well as on making managerial decisions and developing a proper prevention system. All this will ultimately lead to deteriorating labor potential in leading industrial branches and agriculture and will create negative attitudes among young people towards production with a lot of noise at workplaces.

Substantial experience has been accumulated via scientific research on SHL prevalence among workers exposed to occupational noise [12, 15-17]. We should highlight that 
recently morbidity with occupational SHL has grown by 2-2.5 times [18, 19].

Sensorineural hearing loss takes a leading place among occupational diseases [17-22]. Unfortunately, SHL prevalence is still high among workers exposed to occupational noise [16]. Specific weight of SHL among all OD reaches $73 \%$ in workers employed at railways; more than $20 \%$, in machinery operators in agriculture. Hearing loss often results in certain limitations imposed on occupational activities. Thus, SHL is the reason for flying crew members not being allowed to work in $85 \%$ cases [23]. Despite prevention activities accomplished at all levels, occupational diseases of the hearing organs caused by exposure to occupational noise still prevail and there is no descending trend in this prevalence [9, 24-27].

People who suffer from SHL together with vibration disease tend to have a considerable decrease in adaptation potential of the circulatory system [28]. When workers were exposed to these adverse hygienic factors, experts revealed adaptation failure in $14 \%$ examined workers, and adaptation was unsatisfactory in another $43.33 \%$. I.B. Soldatov mentioned complicated polyetiological processes involved in sensorineural hearing loss development among workers with «noisy» occupations as far back as in $1997^{2}$.

Recently obtained data allow paying greater attention to SHL development from the etiological pint of view under exposure to common noise beyond working environment. In this respect, we should mention an interesting study by K.P. Luzhetskiy et al. [29] who examined people living in a zone exposed to a large aviation site. The research allowed revealing bilateral conductive hearing loss among children aged 4-7 in 5\% cases; $30.3 \%$ examined people had functional disorders in the hearing analyzer with mild mixed hearing loss. Results obtained by other authors in their research works also indicate that exposure to noise may be hazardous for schoolchildren and teenagers since they revealed significant deviations in functional state of the hearing organs [30]. Results obtained in those research works substantiate advisability of noise loads on schoolchildren to be taken into account especially in cases when these school children choose occupations involving exposure to occupational noise since «sound attacks» from earphones combined with external noise lead to damage done to hair cells in the internal ear. Long-term exposure to aggressive and loud music (there are NIOSH standards for that factor) results in hearing loss among young «music lovers». We can assume that SHL will occur sooner in such people under exposure to occupational noise than it is expected according to conventional concepts on a usual period of time required for this pathology to develop. It should be taken into account when prevention activities are developed at production. In this respect, some research works are of interest since their results indicate that hearing loss can probably be caused both by occupational factors and loud music in earphones [31].

There was also a study that revealed a necessity to take military service into account when examining hearing loss. The results revealed more apparent hearing loss among workers who had previously served in the army and used small arms against those who didn't have military service in their life [32]. The authors believed that military service was a risk factor that made for earlier hearing disorders. Studies accomplished in Korea also indicate that «military service» is a factor that exerts substantial influence on hearing loss occurrence [3]. In this respect we should note there is a possibility that people who served in tank units, artillery, or aviation would face discrimination when trying to get a job at a noisy production as employers would be willing to «prevent» occupational SHL occurrence among them.

It is also important to remember that workers' bodies are not exposed solely to

\footnotetext{
${ }^{2}$ I.B. Soldatov. Guide on otorhinolaryngology. Moscow, Medistina Publ., 1997, 608 p. (in Russian).
} 
noise at workplaces; noise is usually combined with other hygienic factors such as vibration, unfavorable microclimate, a wide range of chemicals belonging to different hazard categories etc. Therefore, we can assume that this or that pathological process occurs in a body due to complex exposure to a set of such factors and due to strain in all body systems necessary to maintain optimal homeostasis. Some researchers are right to believe it is important to examine effects produced by chemicals, first of all, those that exert apparent impacts on the central nervous system and cause hearing loss among workers [3]. In this respect, certain amount of attention paid by scientists who examine issues related to hearing loss may be drawn to combined effects produced by noise and chemicals. There are no standards for examining their combined effects and it makes the issue truly vital taking into account rapidly developing chemical industry that involves using newly synthesized and frequently aggressive chemicals.

Despite noise as a physical factor has been studied in detail, there are still uncertainties related to overall effects it produces on a body [33]. Data obtained by some authors on ear noise among people who are exposed to occupational noise seem quite interesting [3]. Researchers believe that ear noise may be the first sign that occupational hearing loss is developing and it can lead to disability in future. The authors collected substantial data via questioning but didn't try to reveal any correlations between this fact and workers' age or working experience; still the fact deserves certain attention. Technological processes as well as prevention activities and work and leisure regimes have their specificity in different industrial branches and agriculture; bearing this in mind, we should remember that there are still issues related to regulating noise and vibration occupational factors, assessing risks, as well as developing activities aimed at their prevention [21, 22, 34].

Given that, when assessing occupational risks caused by adverse effects produced on workers' health by long-term exposure to noise, it is important to take into account that noise, apart from exerting these specific impacts on the hearing organs, has apparent biologic effects on many other organs and systems and significantly inhibits adaptation abilities of a body [35-37].

E.L. Bazarova et al. [38] examined workers employed at a metallurgic enterprise; they had substantial clinical data available for analysis and it allowed them to conclude that exposure to noise was a biological stressor «of a great biological activity and could induce pathology occurrence in many organs and systems in a body». A wide range of negative effects produced by noise on a body has been mentioned in multiple works and proven with research results; these results indicate that people who are exposed to noise and vibration have 1.14 more rapid biological ageing against reference groups and their actual biological age is on average more than 10 years greater [39].

Accomplished studies provided evidence that low frequency noises were highly aggressive and it became apparent via increasing chromosome aberrations in bone marrow cells and higher $n m$ DNA contents in blood plasma [33]. Recent research works allowed establishing that wide-band noise caused functional disorders in a body that involved a wide range of physiological manifestations such as headaches, sleeping disorders, fatigue, irritability, etc., and it resulted in poorer life quality and people's working capacity. It allows taking a broader view on negative effects produced by exposure to noise and not confining it to hearing organs vulnerability. At the same time we should note that even though significant damaging effects produced on drivers' health by exposure to noise were established in a study, their adaptation to this factor turned out to be also quite satisfactory. Subjectively, $64 \%$ of the questioned drivers didn't think noise produced any negative effects on them [40].

Scientific experts tend to have the common opinion on adverse effects produced by 
occupational noise on workers' cardiovascular system regardless of an industry they are employed in [41].

There are data on workers with «noisehazardous» occupations having authentic changes in functional parameters of their cardiovascular system with occurring high cardiovascular risks [41-45]. Obviously, it calls for developing new approaches to substantiating and implementing prevention activities aimed at reducing adverse influence exerted by occupational noise on workers' health.

Recent publications tend to concentrate more and more on physical factors (noise and vibration) and their significant role in hypertension occurrence [42, 46-48]. Experts revealed that noise made the greatest contribution in arterial hypertension developing in workers exposed to a set of adverse occupational factors (noise, vibration, aerosols, static and dynamic loads). These specific effects were also confirmed by results obtained via research that focused on assessing risks of arterial hypertension occurrence under exposure to noise and chemical factors [49].

M.A. Zemlyanova et al. proved there was a correlation between arterial hypertension and noise among workers employed at oreprocessing enterprises; they also established that examined workers had endothelial dysfunction. The authors substantiated certain biomarkers that gave a correct picture of endothelial dysfunction in people who were chronically exposed to noise [50].

We should also note that recent studies have established a direct correlation between arterial hypertension prevalence and duration of exposure to occupational noise [47]. The authors showed that examined workers employed at metallurgic enterprises had arterial hypertension in $24.1 \%$ cases if their working experience was 15 years or longer.

Similar results were obtained by $\mathrm{X}$. Li et al. when they examined more than 5,000 workers exposed to noise louder than $85 \mathrm{dBA}$ at their workplaces: in case working experi- ence was longer than 10 years, workers suffered from both hearing loss and arterial hypertension [51]. We should highlight the conclusion in this work that occupational noise caused high risks of both arterial hypertension and hearing loss among workers aged from 30 to 45. S.A. Eselevich et al. also revealed that workers form this age group had primary SHL in case their average working experience under exposure to occupational noise was equal to 6 years [52]. There are research works that provide evidence on not only SHL occurrence caused by occupational noise depending on working experience but also arterial hypertension and dyslipidemia occurrence in such workers. It allows experts to give well-grounded recommendations on arterial hypertension and dyslipidemia correction and on such activities being included into overall prevention programs aimed at hearing loss prophylaxis [53].

In our opinion, certain attention should be paid to research results obtained by authors who examined more than 250,000 thousand people exposed to noise and their workplaces and concluded that it was arterial hypertension that caused hearing loss [54]. Although the authors themselves believe that the mechanisms behind this established fact is still unclear, we came tentatively assume that arterial hypertension results in hypoxia thus reducing oxygen «supply» to the hearing organ; it makes for certain conditions that lead to hearing loss. This fact can be to a certain extent explained by research works where their authors revealed a role played by stria vascularis in the middle ear homeostasis under hypoxia [55].

We should note that people who work under exposure to noise and vibration tend to have disorders of cardiac and neurohormonal regulation $[42,56]$.

We also think that it was rather important to establish that occupational noise had potentiating effects even if it was at levels below threshold but combined with other chemical occupational factors [36]. Thus, even exposure to noise that was only slightly higher 
than permissible levels but combined with exposure to other hygienic factors, first of all, chemical ones, makes it necessary to include additional estimated data into risk assessment criteria when assessing health risks for workers. These data should also be taken into account when prevention programs are substantiated and periodical medical examinations are accomplished.

Many researchers are becoming more and more active in substantiating a «life quality concept» that is related to health of workers who have to face adverse working conditions at their workplaces. It is done in order to provide better grounds for developing advanced risk management technologies. We should note that people who suffer from occupational hearing loss also tend to have lower activity parameters and to feel themselves not healthy; it exerts both direct and indirect influence on their life quality.

There are data in literature on influence exerted by social factors on hearing loss occurrence and these factors are still not being given proper attention when prevention activities are developed. Thus, Chinese researchers applied meta-analysis procedures to examine more than 30 thousand people; it allowed them to establish a correlation between smoking and hearing loss [2]. The research revealed that smoking was a risk factor that could cause this pathology. Bearing in mind that linear dependence is not always apparent we can still note that the maximum negative effect was detected in examined people with their smoking experience exceeding 15 years (taking into account «dose - response» dependence). The authors substantiate their statement that it is important to develop programs on giving up smoking for people who work under exposure to noise. Another interesting conclusion made by the authors is that long-term smoking is a risk factor that causes high risks of many diseases; combined, these diseases may result in hearing loss among workers exposed to elevated occupational noise.

Contemporary demographic processes involve an increase in life expectancy and a decrease in birth rate in Russia; it leads to disproportion in labor resources and social strain. Ultimately, it resulted in retirement age increase. Hygienic science unavoidably has to examine and substantiate effects produced by adverse hygienic factors under long-term exposure regulated by relevant standards and documents. Accomplished studies revealed that in case all significant sanitary-hygienic factors were improved, physical factors held the second rank place as per their contribution made into life expectancy [5].

When assessing adverse effects produced by noise on workers employed in different industries and its contribution into hearing loss, it is necessary to take into account the fact that as working experience becomes longer, developing damages to the hearing organs are aggravated by age-related changes in workers [57].

In scientific literature there are also data on influence exerted by nutrition (metabolic factor) on hearing loss development. There are quite interesting studies accomplished by Korean scientists who examined a correlation between dietary nutrition and hearing loss among elderly people aged 65 . For 3 years 4,742 people underwent a profound medical examination that included audiologic assessment and analysis of their nutrition [58]. To provide a homogenous sampling, the authors took into account body mass index, smoking status, alcohol intake as well as diabetes and arterial hypertension in case history. Results obtained via this 3-year examination allowed establishing a correlation between hearing loss and riboflavin, niacin, and retinol consumption with food. Only one group out of all examined people consumed them in optimal quantities recommended by the $\mathrm{WHO}$, and it allowed the authors to conclude that they were efficient in hearing loss prophylaxis as well as to state that it was possible to use these substances within the overall system for hearing loss prevention.

There are also data on positive effects produced by polyvitamins consumption on 
hearing improvement in examined people [59]. Studies accomplished by British scientists also provide indirect confirmation that alimentary factor plays an important role in hearing loss. In some research greater hearing loss prevalence was detected among people with lower social status and it was related to poorer nutrition quality [31].

Conclusions. Our literature analysis has allowed us to conclude that issues related to adverse impacts exerted by exposure to noise both on the hearing organs and basic body systems are still vital at present. Hearing loss is a problem not only for occupational medicine but it is also an economic and social one. Finding solutions to it will to a great extent contribute not only into improving life quality of workers who are employed at noise-hazardous productions but also into increasing life expectancy of workers employed in leading industrial brunches in the country and making «blue-collar» occupations more prestigious.

Growing life expectancy and an increase in retirement age are necessarily connected to longer working experience under exposure to noise and it will naturally aggravate the considered problem.

A growing period of exposure to a set of occupational factors, noise included, and changing social factors require additional studies on examining the whole range of occupational risks caused by influence exerted by noise on a whole body and the hearing organs in particular. It is also necessary to provide scientific grounds for advanced technologies development within a system for hearing loss prevention and workers' health preservation as it will result in more stable situation with labor potential in leading industrial brunches.

Providing comfortable occupational and social conditions for workers should be viewed as a vital trend in scientific research in the sphere of hygiene and occupational medicine in accordance with primary tasks set with state strategies.

Funding. The research was not granted any sponsor support.

Conflict of interests. The authors declare there is no any conflict of interests.

\section{References}

1. Zheglova A.V. Personalized occupational risk and longevity. Meditsina truda i promyshlennaya ekologiya, 2019, vol. 59, no. 9 - C. 627-628 (in Russian).

2. Li X., Rong X., Wang Z., Lin A. Association between Smoking and noise-induced Hearing Loss: Meta-Analysis of Observational Stadies. Int. J. Environ. Res. Public Health, 2020, vol. 17, no. 4, pp. 1201. DOI: 10.3390/ijerph17041201

3. Kim K.S. Occupational Hearing Loss in Korea. J. Korean Med Sci, 2010, vol. 25, pp. 62-69. DOI: $10.3346 / \mathrm{jkms} .2010 / 25 . \mathrm{S} 62$

4. Bukhtiyarov I.V., Izmerov N.F., Tikhonova G.I., Churanova A.N., Gorchakova T.Yu., Bryleva M.S., Krutko A.A. Work conditions as a risk factor mortality increase in able-bodied population. Meditsina truda i promyshlennaya ekologiya, 2017, no. 8, pp. 43-49 (in Russian).

5. Popova A.Yu., Zaitseva N.V., Onishchenko G.G., Kleyn S.V., Glukhikh M.V., Kamaltdinov M.R. Social and economic determinants and potential for growth in life expectancy of the population in the Russian Federation taking into account regional differentiation. Health Risk Analysis, 2020, no. 1, pp. 4-17 (in Russian). DOI: 10.21668/health.risk/2020.1.01.eng

6. Valeeva E.T., Bakirov A.B., Shaikhlislamova E.R. About the reasons of low detection of occupational diseases in the republic of Bashkortostan. Meditsina truda i promyshlennaya ekologiya, 2019, vol. 59, no. 9, pp. 578-579 (in Russian).

7. Panova I.V., Lashina E.L., Pakseeva V.S. The results of periodic medical examinations in the central Federal district 2016-2018. Meditsina truda i promyshlennaya ekologiya, 2019, vol. 59, no. 9, pp. 716 (in Russian).

8. Panova I.V., Chernov O.E., Pfaff V.F. Mandatory medical examinations as a method of prevention. Meditsina truda i promyshlennaya ekologiya, 2019, vol. 59, no. 9, pp. 717 (in Russian). 
9. Pankova V.B., Vil'k M.F., Daikhes N.A. Hearing loss from noise exposure is an urgent problem of occupational medicine. Meditsina truda i promyshlennaya ekologiya, 2019, vol. 59, no. 9, pp. 713-714 (in Russian).

10. Atamanchuk A.A., Kabanova T.G. Difficulties in diagnosis of occupational diseases in Russia. Meditsina truda i promyshlennaya ekologiya, 2017, no. 9, pp. 11-12 (in Russian).

11. Berkheeva Z.M. Problems of providing occupational health care to employees of agroindustrial complex. Meditsina truda i promyshlennaya ekologiya, 2019, vol. 59, no. 9, pp. 567-568 (in Russian).

12. Gazizov O.M., Amanbekova A.U. Professional sensorineural hearing loss in coal miners. Meditsina truda i promyshlennaya ekologiya, 2019, vol. 59, no. 9, pp. 594-595 (in Russian).

13. Tikhonova I.V. The role of performing and periodical profound medical examinations in the development prevention of occupational hearing disorders. Byulleten' VSNTs SO RAMN, 2005, vol. 40, no. 2, pp. 92-94 (in Russian).

14. Adeninskaya E.E., Simonova N.I., Mazitova N.N., Nizyaeva I.V. The principles of noise induced hearing loss diagnostics in modern Russia (systematic review). Vestnik sovremennoi klinicheskoi meditsiny, 2017, vol. 10, no. 3, pp. 48-55 (in Russian).

15. Chebotarev A.G., Bulgakova N.V., Khakimova O.O. Gigienicheskaya otsenka shuma i patologii organa slukha $\mathrm{u}$ rabochikh gorno-metallurgicheskikh predpriyatii [Hygienic assessment of noise and acoustic apparatus pathologies among workers employed at mining and metallurgical enterprises]. Gornaya promyshlennost', 2017, vol. 132, no. 2, pp. 64-66 (in Russian).

16. Professional'nye zabolevaniya [Occupational diseases]. In: N.F. Izmerov [et al.] eds. Moscow, 1996, vol. 1, 336 p. (in Russian).

17. Garipova R.V., Safina K.R., Nigmatullina G.R. Structure of occupational morbidity of employees of a large machine-building enterprise. Meditsina truda i promyshlennaya ekologiya, 2019, vol. 59, no. 9, pp. 596-597 (in Russian).

18. Fedina I.N., Preobrazhenskaya E.A. Features of noise-induced hearing loss in modern conditions. Meditsina truda i promyshlennaya ekologiya, 2017, no. 9, pp. 200-201 (in Russian).

19. Trofimova K.I., Gibadulina I.Yu., Bulgakova M.V. Pharmacotherapy for combined cardiovascular pathology and occupational neurosensory deafness in workers exposed to noise. Meditsina truda i promyshlennaya ekologiya, 2017, no. 9, pp. 194-195 (in Russian).

20. Bezrukova G.A., Novikova T.A., Shalashova M.A. The role of vibro-acoustic factor in formation of occupational morbidity of agricultural workers. Meditsina truda i promyshlennaya ekologiya, 2017, no. 9, pp. 22-23 (in Russian).

21. Vil'k M.F., Pankova V.B., Kaptsov V.A. Traffic noise as a risk factor for occupational deafness (exemplified by air and railway transport). Meditsina truda i promyshlennaya ekologiya, 2017, no. 9, pp. 36-37 (in Russian).

22. Tyurin A.V., Vyal'tsina N.E., Kulbaisov A.M. Occupational morbidity in the Orenburg region. Meditsina truda i promyshlennaya ekologiya, 2019, vol. 59, no. 9, pp. 780-781 (in Russian).

23. Romeiko V.L., Ivleva G.P. Hygienic assessment of acoustic load on flight crew members of civil aircrafts. Meditsina truda i promyshlennaya ekologiya, 2017, no. 9, pp. 161 (in Russian).

24. Adeninskaya E.E., Simonova N.I., Savel'ev A.A., Mukharamova S.S. Auditory threshold raising dependence on production risk factors in air crew members. Vestnik sovremennoi klinicheskoi meditsiny, 2018, vol. 11, no. 1, pp. 17-22 (in Russian).

25. Pankova V.B., Fedina I.N., Volgareva A.D. Professional'naya neirosensornaya tugoukhost': diagnostika, profilaktika, ekspertiza trudosposobnosti [Occupational sensorineural hearing loss: diagnostics, prevention, and working capacity examination]. In: I.A. Doikhes ed. Moscow, Izdatel'skotorgovaya korporatsiya «Dashkov i Ko» Publ., 2017, 330 p. (in Russian).

26. Volgareva A.D., Karimov L.K., Bakirov A.B., Shaikhlislamova E.R., Gimranova G.G., Muldasheva N.A., Chudkovets G.M., Gazizova N.R., Faizullina G.N. Relevant problems of early diagnosis of neuro-sensor hearing loss in petrochemical workers. Meditsina truda i ekologiya cheloveka, 2019, no. 1, pp. 5-10 (in Russian). 
27. Pankova V.B., Fedina I.N., Bomshtein N.G., Volokhov L.L., Serebryakov P.V. The modern principles of rehabilitation of hearing disorders in workers of noise occupations. Zdravookhranenie Rossiiskoi Federatsii, 2018, vol. 62, no. 3, pp. 147-151 (in Russian).

28. Ereniev S.I., Plotnikova O.V. Adaptive potential of the circulatory system in patients with vibration disease and sensorineural hearing loss. Meditsina truda i ekologiya cheloveka, 2019, vol. 59, no. 9, pp. 623-624 (in Russian).

29. Luzhetskii K.P.., Ustinova O.Yu., S.V. Kleyn, Koshurnikov D.N., Vekovshinina S.A., Chigvintsev V.M. Peculiarities of production-related diseases in miners employed at deep mining of chromic ores. Meditsina truda i promyshlennaya ekologiya, 2018, no. 10, pp. 12-16 (in Russian).

30. Popova O.A., Goncharova I.G., Kartysheva S.I. Problems auditory fatigue and auditory adaptation in children and adolescents. Materialy V Vserossiiskoi konferentsii «Novoi shkole zdorovye deti», 2018, pp. 130-132 (in Russian).

31. Dawes P., Fortnum H., Moore D.R., Emsley R., Norman P., Cruickshanks K., Devis A. [et al.]. Hearing in middle age: a population snapshot of 40-69 year old in the UK. Ear Hear, 2014, vol. 35, no. 3, pp. e44-e51. DOI: 10.1097/AUD.0000000000000010

32. Churkin D.V., Lastkov D.O., Antropova O.S. Evaluation of the expression of hearing disorders in participants of a local military conflict with preceding work experience in conditions of production noise. Meditsina v Kuzbasse, 2018, vol. 17, no. 2, pp. 9-14 (in Russian).

33. Vasil'eva I.N., Bespalov V.G., Zinkin V.N. Low-frequency noise as a hazard increasing occurrence of chromosomal aberrations and promoting cell death. Meditsina truda i promyshlennaya ekologiya, 2017, no. 3, pp. 22-26 (in Russian).

34. Prokopenko L.V., Kravchenko O.K., Kur'erov N.N. Problems of regulation for noise and vibration influence on automobile drivers and prevention measures. Meditsina truda i promyshlennaya ekologiya, 2017, no. 9, pp. 158-159 (in Russian).

35. Concha-Barrientos M., Camobell-Lendrum D., Steenlend H. Occupational noise: assessing the burden of disease from work-related hearing impairment at national and local levels. WHO Enviromental Burden of Diseases Series. Geneva, World Health Organization Publ., 2004, no. 9, pp. 41 (in Russian).

36. Vasyutkina D.I. Proizvodstvennyi shum i ego vliyanie na organism cheloveka [In-plant noise and its impacts on a human body]. Vestnik BGTU im. V.G. Shukhova, 2013, no. 1, pp. 125-128 (in Russian).

37. Denisov E.I., Chesalin P.V. Nonspecific effects of noise expo-sure. Gigiena i sanitariya, 2007, no. 6, pp. 54-57 (in Russian).

38. Bazarova E.L., Fedoruk A.A., Roslaya N.A., Osherov I.S., Babenko A.G. Assessment of occupational risk caused by noise exposure in workers at metallurgical plant subunits under modernization. Meditsina truda i promyshlennaya ekologiya, 2019, vol. 59, no. 3, pp. 142-148 (in Russian).

39. Ereniev S.I. Plotnikov O.V. Biological age and rates of aging of patients with vibration disease and bilateral sensorineural hearing loss. Meditsina truda i promyshlennaya ekologiya, 2019, vol. 59, no. 9, pp. 624-625 (in Russian).

40. Klimova M.G., Khristoforova N.K. Physical influence of noise on drivers health. Vestnik RUDN. Seriya: Ekologiya i bezopasnost' zhiznedeyatel'nosti, 2012, no. 1, pp. 38-46 (in Russian).

41. Nosov A.E., Baidina A.S., Vlasov E.M., Alekseev V.B. Analysis of the heart rate variability in cardiac abnormalities in workers employed in oil production. Gigiena i sanitariya, 2016, vol. 95, no. 1, pp. 41-45 (in Russian).

42. Melent'ev A.V., Serebryakov P.V., Shcheglova A.V. Influence of noise and vibration on nervous regulation of heart. Meditsina truda i promyshlennaya ekologiya, 2018, no. 9, pp. 19-23 (in Russian).

43. Popov M.N. Vascular factor in development of professional neurotouch relative deafness. Rossiiskaya otorinolaringologiya, 2014, vol. 68, no. 1, pp. 182-183 (in Russian).

44. Melent'ev A.V., Serebryakov P.V. The role of physical factors of the working environment in the formation of arterial hypertension. Meditsina truda i promyshlennaya ekologiya, 2019, vol. 59, no. 9, pp. 692-693 (in Russian).

45. Izmerov N.F., Bukhtiyarov I.V., Ermakova M.A., Shpagina A.A. Features of hemostasis system and vascular epithelium growth factor in arterial hypertension with high occupational risk. Meditsina truda i promyshlennaya ekologiya, 2014, no. 3, pp. 1-6 (in Russian). 
46. Preobrazhenskaya E.A., Sukhova A.V., Izmailova O.A. Clinical and functional state of cardiovascular system in workers exposed to noise and vibration. Meditsina truda i promyshlennaya ekologiya, 2017, no. 9, pp. 158 (in Russian).

47. Tiunova M.I., Vlasova E.M., Nosov A.E., Ustinova O.Yu. Influence of industrial noise on the development of arterial hypertension in workers of metallurgical manufactures. Meditsina truda $i$ promyshlennaya ekologiya, 2020, vol. 60, no. 4, pp. 264-267 (in Russian).

48. Atamanchuk A.A., Dmitruk L.I., Gorenkov R.V. The role of adverse occupational factors in the formation of hypertension in workers. Meditsina truda i promyshlennaya ekologiya, 2019, vol. 59, no. 9, pp. 546-547 (in Russian).

49. Fedina I.N., Serebryakov P.V., Smolyakova I.V., Melent'ev A.V. Evaluation of arterial hypertension risk under exposure to noise and chemical occupational hazards. Meditsina truda i promyshlennaya ekologiya, 2017, no. 2, pp. 21-26 (in Russian).

50. Zemlyanova M.A., Zaitseva N.V., Kir'yanov D.A., Shlyapnikov D.M., Lebedeva T.M. Biomarkers of work-related endothelial dysfunction in employees of ore-dressing production occupied in conditions of long-term noise exposure. Gigiena i sanitariya, 2017, vol. 96, no. 1, pp. 56-62 (in Russian).

51. Li X., Dong Q., Wang B., Songan H., Zhu B. The Influence of Occupational Noise Exposure on Cardiovascular and Hearing Conditions among Industrial Workers. Sci. Rep., 2019, vol. 9, pp. 11524. DOI: 10.1038/541598-019-47901-2

52. Eselevich S.A., Balunov V.D., Kolesnikova V.A. Principles of formation of risk groups among employees at the enterprise in the Leningrad region. Meditsina truda i promyshlennaya ekologiya, 2019, vol. 59, no. 9, pp. 625-626 (in Russian).

53. Pfaf V.F., Gorokhova S.G., Luzina K.E., Yanushkina E.S., Prigorovskaya T.S., Muraseeva E.V., Dragin S.P., At'kov A.Yu. Occupational deafness in workers of locomotive crew and its association with risk factors. Meditsina truda i promyshlennaya ekologiya, 2016, no. 2, pp. 33-37 (in Russian).

54. Wang B., Han L., Dai S., Li X., Cai W., Yang D., Chen L., Wang N., Zhu B., Zhang J. Hearing Loss Characteristics of Workers with Hypertension Exposed to Occupational Noise: A Cross-Sectional Study of 270,033 Participants. Hindawi BioMed Research International, 2018, vol. 2018 , pp. 7. DOI: $10.1155 / 2018 / 8541638$

55. Ciuman R.R. Stria vascularis and vestibular dark cells: characterization of main structures responsible for homeostasis, and their pathophysiological relations. The Journal of Laryngology \& Otology, 2009, vol. 123, no. 2, pp. 151-162. DOI: 10.1017/S0022215108002624

56. Lapko I.V., Kir'yakov V.A., Pavlovskaya N.A., Zheglova A.V., Oshkoderov O.A. The impact of physical factors on the complex neurohormonal regulation of workers in mining and engineering. Sanitarnyi vrach, 2015, no. 2, pp. 9-15 (in Russian).

57. Dobie R.A. The burdens of age-related and occupational noise-induced hearing loss in the United States. Ear Hear, 2008, vol. 29, no. 4, pp. 565-577. DOI: 10.1097/AUD.0b013e31817349ec

58. Kim T.S., Chung J.W. Associations of Dietary Riboflavin, Niacin, and Retinol with Agerelated Hearing Loss; An Analysis of Korean National Health and Nutrition Examination Survey Data. Nutrients, 2019, vol. 11, no. 4, pp. 896. DOI: 10.3390/nu11040896

59. Spankovich C., Li Prell C.G. Healthy diets, healthy hearing: National health and nutrition examination survey, 1999-2002. Int. J. Audiol., 2013, vol. 52, no. 6, pp. 369-376. DOI: $10.3109 / 14992027.2013 .780133$

Spirin V.F., Starshov A.M. On certain issues related to chronic exposure to occupational noise and impacts exerted by it on workers' bodies (literature review). Health Risk Analysis, 2021, no. 1, pp. 185-194. DOI: 10.21668/health.risk/2021.1.19.eng

Received: 06.11.2020

Accepted: 03.03.2021

Published: 30.03 .2021 